\title{
Effect of High Salinity Water on Growth and Survival of Penaeid Postlarvae from the Red Sea at Different Stocking Densities
}

\author{
Adnan Jameel Salama \\ Faculty of Marine Science, \\ King Abdulaziz University, Jeddah, Saudi Arabia
}

\begin{abstract}
A study undertaken to assess the effect of high salinity water on the growth and survival of Penaeus monodon, P. indicus and $P$. semisulcatus postlarvae in cylindrical 5000-1 fibreglass tanks for 60 days under monoculture in saline water from the Red Sea. Three different stocking densities tested were 50,100 and 200 postlarvae $/ \mathrm{m}^{2}$ with initial weight of $0.09 \mathrm{~g}$. The highest net weight gained, survival rates and feed conversion ratio were obtained in the lowest stocking density $\left(50\right.$ postlarvae $\left./ \mathrm{m}^{2}\right)$ in all three species. High salinity caused an effect on the growth, survival rates, and feed conversion ratio of the penaeid postlarvae.
\end{abstract}

\section{Introduction}

Penaeid shrimps are one of the most important resources of the coastal fisheries in Saudi Arabia. Shrimp culture is still in its infancy stage in the Kingdom of Saudi Arabia and shrimp culture practices are not or not often documented. In recent years, developments have been made in shrimp's aquaculture all over the world. Different ranges of salinity have been reported to support the survival and better growth of $P$. monodon ${ }^{[1-, 5]}$. A high rate of survival and good growth of $P$. monodon in a freshwater lake has been reported from the Philippines ${ }^{[6]}$. Monoculture of $P$. monodon in rivers, irrigation channels and ground water has been successfully accomplished in Thailand ${ }^{[7]}$. However, there is little information available on monoculture of $P$. monodon, $P$. indicus and $P$. semisulcatus in higher salinities of 38 to $39 \%$. Hence the present study was undertaken to assess the growth and culture potential of $P$. monodon, $P$. indicus and $P$. semisulcatus in saline water under monoculture in Jeddah, Saudi Arabia. 


\section{Materials and Methods}

The culture system consisted of 18 cylindrical 5000-1 fibreglass tanks. Three tanks were used for each species with two replicates for each density. The system was located outdoor in an aerial space at the Faculty of Marine Science (FMS), King Abdulaziz University, Obhor Campus. The experiment was conducted from October $26^{\text {th }}$ to December $25^{\text {th }} 1998$. In this trial three stocking densities per species namely 50,100 and $200 / \mathrm{m}^{2}$ postlarvae were used. The postlarvae (PL30) have mean weights of $0.09 \mathrm{~g}$. They were obtained from the Fish Farming Center (FFC) of the Ministry of Agriculture (Jeddah). Experimental duration was 60 days for each trial. Shrimp was fed with $40 \%$ protein at the rate of $30 \%, 25 \%, 20 \%$, and $10 \%$ of the shrimp biomass every fifteen days. The diet was given four times daily. Ten percent of the shrimp stocked was sampled every two weeks for the purpose of adjusting feed requirement of the organism. Water exchange rate for the system was approximately $40 \%$ of the water volume per day. Continuous aeration was provided. Salinity, water temperature, $\mathrm{pH}$ and dissolved oxygen were measured daily.

\section{Results}

The mean values of the different water quality parameters along with standard deviation are presented in Table 1 . The Red Sea has relatively high salinity values. In the present investigation, postlarvae of $P$. monodon exhibited a growth rate of $0.067,0.056$ and $0.051 \mathrm{~g} /$ day and attained a total of 4.02, 3.36 and 3.06 grams at the end of the culture experiment (60 days) with 80,68 and $59 \%$ survival for the stocking density of 50,100 and 200 postlarvae $/ \mathrm{m}^{3}$ respectively. Average feed conversion rate was 2.77 for the three densities (Table 2).

TABLE 1. Mean values with standard deviation of water quality parameters recorded during the culture operation.

\begin{tabular}{|l|c|}
\hline \multicolumn{1}{|c|}{ Parameters } & Values \\
\hline Water level $(\mathrm{m})$ & $1.5 \pm 0.08$ \\
\hline Temperature $\left({ }^{\circ} \mathrm{C}\right)$ & $30.1 \pm 1$ \\
\hline $\mathrm{pH}$ & $8.06 \pm 0.5$ \\
\hline Dissolved oxygen $(\mathrm{mg} / \mathrm{l})$ & $5.57 \pm 1.2$ \\
\hline Salinity $(\mathrm{ppt})$ & $38.5 \pm 0.5$ \\
\hline
\end{tabular}


TABLE 2. Weight gain, Feed Conversion ratio (FCR), and survival rates of the three penaeid species at three different stocking densities.

\begin{tabular}{|c|c|c|c|c|}
\hline Species & $\begin{array}{c}\text { Stocking } \\
\text { density } / \mathrm{m}^{2}\end{array}$ & $\begin{array}{c}\text { Weight } \\
\text { gain } \\
\text { (g/day) }\end{array}$ & FCR & $\begin{array}{c}\text { Survival } \\
\text { rate } \\
(\%)\end{array}$ \\
\hline \multirow{3}{*}{ P. monodon } & 50 & 0.067 & 2.63 & 80 \\
& 100 & 0.056 & 2.71 & 68 \\
& 200 & 0.051 & 2.97 & 59 \\
\hline \multirow{3}{*}{ P. indicus } & 50 & 0.051 & 2.38 & 78 \\
& 100 & 0.044 & 2.60 & 68 \\
& 200 & 0.042 & 2.85 & 60 \\
\hline \multirow{3}{*}{ P. semisulcatus } & 50 & 0.052 & 2.47 & 48 \\
& 100 & 0.046 & 2.54 & 39 \\
& 200 & 0.043 & 2.98 & 37 \\
\hline
\end{tabular}

Postlarvae of $P$. indicus got a growth rate of $0.051,0.044$ and $0.042 \mathrm{~g} /$ day (Tables 1+2), and attained 3.06, 2.64 and 2.52 grams at the end with a survival rate of 78,68 and $60 \%$ for the 3 different stocking densities respectively. Average feed conversion rate was 2.61 for the three stocking densities.

Postlarvae of $P$. semisulcatus gained a growth rate of $0.052,0.046$ and 0.043 g/day and attained 3.12, 2.76 and 2.58 grams after 60 cultured days with a survival rate of 48,39 and $37 \%$ for the different stocking densities respectively. Average feed conversion rate was 2.66 for the three densities.

\section{Discussion}

The Red Sea has relatively high salinity values, when compared with the optimal salinity for shrimp ${ }^{[8]}$. Stocking density of 50 postlarvae $/ \mathrm{m}^{2}$ gave the highest average net weight gain among the cultured species. Growth rates obtained in the present experiment seem to pass the growth rates reported for P. monodon by ${ }^{[9]}$. Sultan et al. ${ }^{[10]}$ obtained higher average daily increment from 0.15 to $0.194 \mathrm{~g}$ in nylon cages at stocking density of 6 per square meter as compared to the present study with 0.04 to $0.06 \mathrm{~g} /$ day. The results obtained by ${ }^{[11-13]}$ was good, but the results of the present study are higher comparable to the data they obtained. Although shrimps could be grown in a wide range of salinities, it was believed that the result of low weight increment is due to the higher salinity (38 to $39 \%$ o). Raj and Raj ${ }^{[14]}$ working on the same species, obtained the highest mean weight gain of $0.048 \mathrm{~g}$ per day at $25 \%$ and $0.010 \mathrm{~g}$ per day at $45 \%$ for $P$. monodon, while our findings showed a better weight increment per day of $0.067,0.056$ and $0.051 \mathrm{~g}$ for the 50,100 and 200 postlarvae $/ \mathrm{m}^{2}$, respectively. 
The monitored salinities were at the upper tolerable limit of the shrimps and may cause stress for the shrimp. Aside from growth as a function of diet, a great proportion of energy is diverted to osmo-regulation ${ }^{[15]}$.

The growth values recorded in this present study are better than that of 0.044 $\mathrm{g}$ /day experienced by ${ }^{[16,17]}$ obtained lower growth increment in $25 \%$ of 0.029 and $0.025 \mathrm{mg}$ in 50\% for brown shrimp (P. aztecus). Overall results of the different treatments in this study show a higher daily growth increment than 0.039 $\mathrm{g} /$ day reported by ${ }^{[18]}$ for $P$. rnonodon cultured in pond at stocking density of 20.000 juveniles per hectare for 80 days.

The result of the study indicates that high survival rate occurred with low stocking density. It was observed that death of $P$. semisulcatus and $P$. rnonodon was due to post molting. Ponce ${ }^{[19]}$ reported that cannibalism in the intensive culture of shrimp is natural even with enough natural and supplementary feeds in grow-out ponds. This occurrence however was not observed in P. indicus. The obtained survival rate in this study is a little lower than the survival rate reported by ${ }^{[18]}$. But survival rates recorded for both $P$. rnonodon and $P$. indicus in the present study are better than that of $58 \%$ experienced by ${ }^{[20]}$ with $P$. rnonodon at very low stocking density of $1.5 \mathrm{~m}^{2}$. However, the percentage recovery in the present study confirms the view of ${ }^{[21]}$ who reported that survival rates of $60 \%$ to $80 \%$ was to be expected under suitable rearing conditions. The stocking density and the kind of environment play a vital role in the survival of the stock. It was observed that due to the very high stocking density in the present study (50 to 200 postlarvae $/ \mathrm{m}^{2}$ ) and higher salinity (39\%), rearing in tanks, cannibalism increased during molting stages. In pond with stocking density of only 20,000 per hectare used by ${ }^{[18]}$, the shrimp has a greater possibility of hiding from predators during molting.

Feed conversion ratio (FCR) was influenced by the survival rate. The result shows that the best FCR was obtained from the highest survival rate. The FCR pattern is similar to the different treatments, for the three species. As survival rate increases, there would be more individuals that would eat the food given, and more flesh to be produced. The reflected higher values for FCR for the $P$. monodon is attributed to its bigger size that would need more food as compared to the smaller species. $P$. indicus and P. semisulcatus ${ }^{[16,17]}$ attained higher FCR of 1.25 for $25 \%$ and 1.52 for $50 \%$ for brown shrimp (P. aztecus) with feeding levels similar to ours when compared to all our results of 2.43, 2.44 and 2.98 for high salinity concentration of $38.9 \%$.

In all treatments, the lowest stocking density $\left(50\right.$ larvae $\left./ \mathrm{m}^{2}\right)$ registered the highest survival rate. Even with high stocking density and low survival rate, results indicate that the three penaeid species showed high potential for commercial production along at the higher salinity of the Red Sea water. 


\section{Acknowledgements}

This research project was carried out at the Faculty of Marine Sciences with the support of King Abdulaziz Science City and Technology, (KASCT). I wish to thank the Fish Farming Center, Ministry of Agriculture, Jeddah, Saudi Arabia for their assistance in providing shrimp postlarvae to carry out these experiments. Special thanks are due to Mr. Salim Al-Thobaity, and also Mr. Nelson Doren the technician, who helped me a lot.

\section{References}

[1] Muthu, M.S., Site selection and type of farms for coastal aquaculture of prawns, pp. 97-106. (1980). In: Proceedings of the First Mat. Symposium on 'Shrimp Farming'. Marine Products Export Development Authority, Bombay, India.

[2] Rajyalakshmi, T., Manual on brackishwater aquaculture. Bull. Cent. Inland Fish. Res. Inst. India 31: 26, (1980).

[3] Chen, H.C., Water quality criteria for farming of shrimp, P. monodon. In: Y. Taki, J.H. Primavera and J.A. Llobrera (eds.) Proceedings of the First International Conference on the Culture of Penaeid Prawn/Shrimps. Southeast Asian Fisheries Development Centre, Iloilo City, Philippines. (1984).

[4] Chanratchakool, P., Turnbull, J.F. and Limsunean, C., Health management in shrimp ponds. Aquatic Animal Health Research Institute, Department of Fisheries, Kasetsart University, Bangkok, (1994).

[5] Karthikeyan, J., Aquaculture (shrimp farming) - its influence on environment. American Society of Civil Engineers, Calcutta, India. Technical paper submitted to the Seminar on Our Environment, Its Challenges to Development Projects, 9-10 September 1994.

[6] Pantastico, J.B., Research paper presented at the Technical Consultation on Available Aquaculture Technology in the Philippines. 8-10 February, p: 5, (1979). South East Asian Fisheries Development Centre, Aquaculture Department, Tigbauan, Iloilo, Philippines

[7] Raghunath.B. Shivappa and Hambrey, J.B., Tiger shrimp culture in freshwater. Infofish International 4: 32-26, (1997).

[8] Bukhari, F.A., Jones, D.A. and Salama, A.J., Optimal salinities for the culture of Penaeus indicus from the Red Sea. JKAU: Mar. Sci., Vol. 8: 137-147, (1997).

[9] Pascual, F.P. and Bandonil, L., Preliminary biological evaluation of some formulated feeds for P. monodon. Quarterly Res. Report. Aquaculture Dept., SEAFDEC 1: 32-33 (1977).

[10] Sultan. K.M.M., Siddhaj, U. and Ramachandra, M., An artificial shrimp feed compounded with frog flesh waste as the main ingredient. Proceedings on Symposium on Coastal Aquaculture, 1: 344-348 (1982).

[11] Liao, I.C., Status and problems of shrimp culture in Taiwan. In: I.C. Liao and Hirano (Eds.) Proceedings of ROC-Japan Symposium on Mariculture. TML Conference Proceedings, (1984). 1: 81-98. Tungkang Marine Laboratory, Tungkang, Pintung, Taiwan, ROC.

[12] Sasai, K., Bitter experience in grass shrimp culture. Fish Culture, 18(11): 63-67 (1981).

[13] Forster, J.R.M. and Beard, T.W., Growth experiments with the shrimp Palaemon serratus Pennant fed with fresh and compounded foods. Fishery Invest. Ser. 11, 27(7): 6 (1974).

[14] Raj, R.P. and Raj, P.J.S., Effect of salinity on growth and survival of three species of penaeid shrimps. Proceedings on Symposium on Coastal Aquaculture 1: 236-246 (1982).

[15] Gordon, M.S., Animal Physiology: Principles and Adaptation. McMillan Pub. Co. Inc. New York. 585 (1982). 
[16] Calvin, P.M., Nutritional studies on penned shrimp: protein requirements in compounded diets for juvenile Pegasus indices. Aquaculture, 7(4): 315-326 (1976).

[17] Venkatamiah, A.G., Laksmi, J. and Gunner, G., The effects of salinity, temperature, and feeding levels on food conversion, growth and survival rates of shrimp, P. Aztecs. Fooddrugs from the Sea Proceedings. University of Rhode Island. Kingston, Rhode Island Marine Technological Society, Washington D.C., (1972).

[18] Sundarajan, D.S., Chandraand B.V. and Venkatesan, V., Nonculture of tiger shrimp, $P$. monotone Fabrics in a brackish water pond at Madras, India. Aquaculture 16: $73-75$ (1979).

[19] Ponce, G.S., Preparation, operation and management of intensive shrimp farm. Paper presented on the Training Workshop on the principles and technology in the intensive and semintensive shrimp culture. DA-BFAR Region 4, Oriental Mindoro, Philippines (1987).

[20] Athithan, S., Francis, T., Ramanathan, N. and Ramadhas, S., A note on monoculture of Penaeus monodon in a hardwater seasonal pond. Naga, The ICLARM Quarterly, Vol. 24, No. 3 \& 4: 14-15 (2001).

[21] Krantz, C.G. and Norris, J., Proceedings on 6th annual workshop, Mariculture Society. Seattle, Washington. 48-57 (1975). 


\title{
تأثير الملوحة العالية على نمو وحياة يرقات ربيان عائلة البينيدي من البحر الأحمر فى كثافات تخزينية مختلفة
}

\author{
عدنان جميل سلامه \\ كلية علوم البحار ، جامعة الملك عبدالعزيز

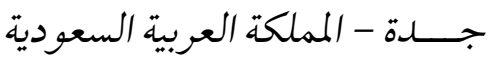

المستخلص. لقد تمت الدراسة لمعرفة تأثير الملوحة العالية لمياه البحر

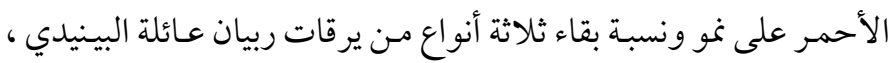

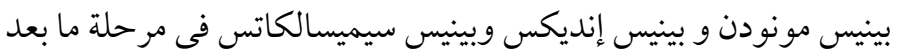

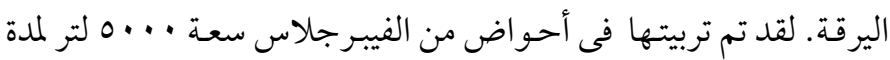

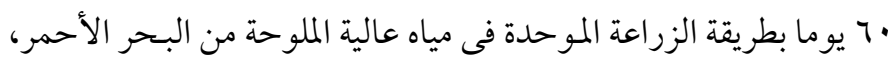

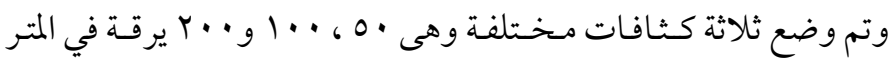

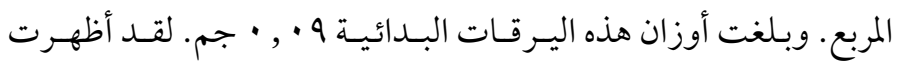

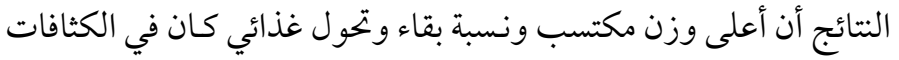

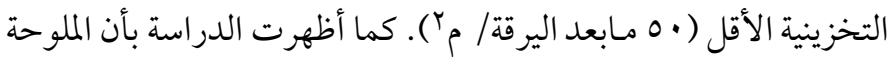

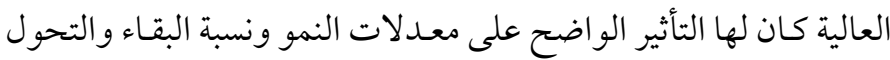
الغذائى ليرقات الربيان (مرحلة ما بعد اليرقة). 